EPiC Series in Engineering
Volume 3, 2018, Pages 1744-1751
HIC 2018. 13th International
Conference on Hydroinformatics

\title{
Novel drought hazard monitoring framework for decision support under data scarcity
}

\author{
Roberto A. Real-Rangel ${ }^{1,2}$, Adrián Pedrozo-Acuña ${ }^{1}$, J. Agustín Breña- \\ Naranjo $^{1}$, Víctor H. Alcocer-Yamanaka ${ }^{3}$ \\ ${ }^{1}$ Institute of Engineering, National Autonomous University of Mexico, Mexico \\ ${ }^{2}$ Program of Master and Doctorate in Civil Engineering, National Autonomous University of \\ Mexico, Mexico \\ ${ }^{3}$ National Water Commission, Mexico \\ rrealreiingen.unam.mx
}

\begin{abstract}
Droughts are among the weather-related disasters, which affects most people around the world. Its large spatial extent and slowly, creeping onset, makes it difficult to define its start and end. Indeed, monitoring and early warning systems for drought hazards are recognized as critical activities of risk governance. Nevertheless, in many regions of the world, the scarcity of direct observations of climatological and hydrological variables, hinder an adequate follow-up and investigation of this phenomenon. This paper introduces a novel framework to generate drought hazard maps and time series, at national and regional levels, based on univariate and multivariate standardized drought indices. Notably, we utilize freely and globally available, gridded datasets of hydrological variables derived from remote sensing and data assimilation systems (e.g., rainfall, soil moisture, streamflow), which are verified against in situ measurements. A good performance of the framework is documented through the comparison of results against observed drought events in Mexico. This paves the road towards its use in other regions of the world, where data scarcity is an issue for drought monitoring activities.
\end{abstract}

\section{Introduction}

During last twenty years, drought has caused economic losses at global scale estimated in 5000 million dollars and it has directly affected 1100 million of persons, from which 22000 have been fatal casualties (CRED, 2015). In this scenario, drought risk reduction planning activities are essential part of development programs of all countries. Through a series of drought risk reduction measures, it is possible to protect both human and economic assets from extreme natural phenomenon such as floods and droughts (UNISDR \& WMO, 2012). 
In this context, assess and anticipate natural indicators by mean of monitoring and early warning contributes to reduce the impacts of future events (Wall \& Hayes, 2016). Nonetheless, many regions in the world have limited, obsolete or, even, absent gauging networks for direct observation of the meteorological and hydrological variables needed to capture the onset and persistence of droughts (i.e., precipitation, runoff, soil moisture, etc.). This situation, besides the evolution and improvement of remote sensing techniques and instruments, has motivated the widening of the combined usage of remote sensing derived data, ground-based observations and land surface models in to obtain global datasets of variables of the terrestrial water cycle.

This work introduces a novel, objective framework for the generation of drought intensity and magnitude maps and time series, using freely and globally available, gridded datasets of hydrological variables derived from remote sensing and data assimilation systems. In particular, here we use the Modern-Era Retrospective analysis for Research and Applications, version 2 (MERRA-2) produced by the Global Modelling and Assimilation Office from NASA, which provides monthly data beginning in 1980 to the current date. The following sections will describe in detail the framework, its products and application.

\section{Methods}

\subsection{Drought monitoring framework}

The drought severity is assessed based on its intensity, SDI, and its magnitude, M. The results are reported in form of maps and time series, which helps stakeholders to plan based on an objective quantification of the drought hazard. This is particularly important in Mexico, where the official drought declarations by the National Water Commission were lacking an objective criterion. A program build in Python language, called pySDI, linked to the Geographic Information System GRASS-GIS in order to generate the maps of results, performs all the computations. Figure 1 synthesizes the methodology followed by the framework here presented.

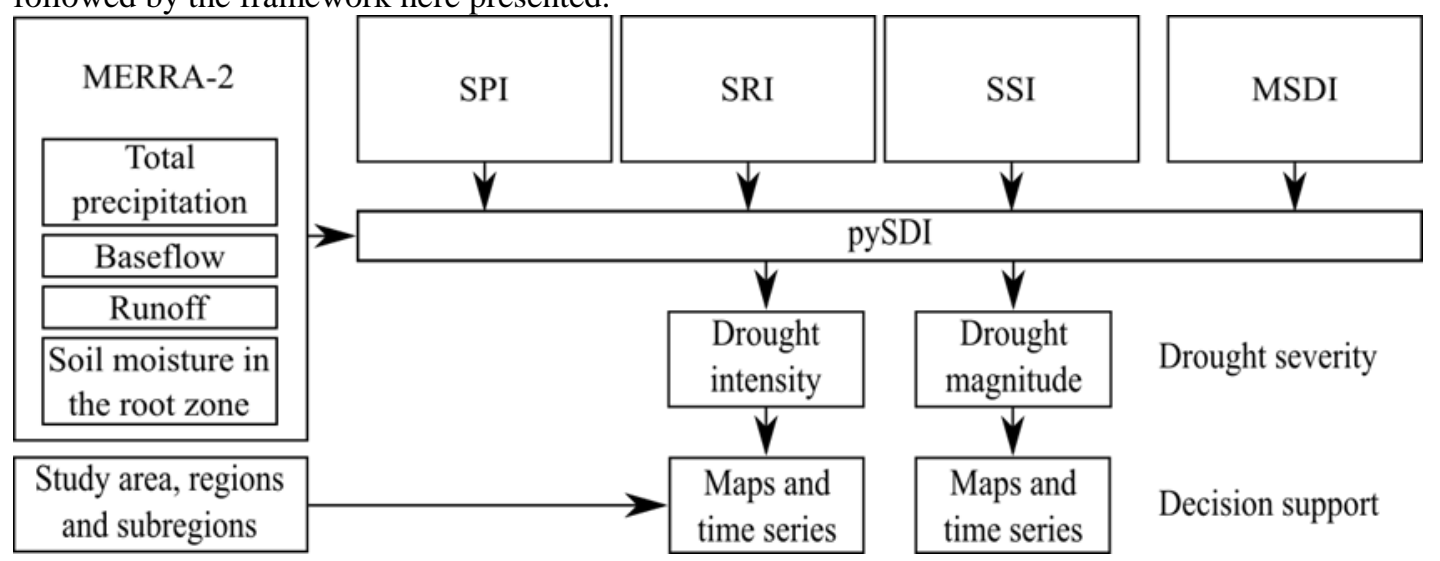

Figure 1. Framework scheme.

\subsection{Data}

The input data for the framework are the hydrological and climatological variables derived from the NASA's reanalysis product Modern-Era Retrospective Analysis for Research and Applications, version 2 (MERRA-2; Gelaro et al., 2017). MERRA-2 uses the Atmospheric General Circulation Model GEOS5 and its data assimilation system to generate atmospheric reanalysis. Reanalysis combines fields 
derived from simulations with direct observations with irregular spatial and temporal resolutions in order to get gridded global meteorological datasets.

The variables extracted from MERRA-2's datasets are total precipitation in land (PRECTOTLAND), baseflow flux (BASEFLOW), overland runoff (RUNOFF), and the water content in the root zone (RZMC). The variables selection was based on the main elements that describes the drought propagation process, from a meteorological drought (lack of precipitation), to an agricultural drought (lack of foil moisture), to a hydrological drought (lack of discharge in streams and low levels in water bodies).

\subsection{Drought characterization}

The most common way to assess droughts severity is using drought indices, which are numeric values that reflect the water availability conditions based on one indicator (univariate indices) or the aggregation of multiple indicators (multivariate indices). The framework developed estimates the following univariate nonparametric standardized drought indices (SDI): Standardized Precipitation Index (SPI; McKee, Doesken, \& Kleist, 1993), Standardized Runoff Index (SRI; Shukla \& Wood, 2008) and the Standardized Soil Moisture Index (SSI; Hao \& AghaKouchak, 2013), derived as proposed by Farahmand \& AghaKouchak (2015). Besides, it is computed the nonparametric Multivariate Standardized Drought Index (MSDI; Hao \& AghaKouchak, 2013, 2014) for precipitation, soil moisture and runoff. Advantages of SDI are its ease of computation, its capability to compare drought conditions between different locations and that it may be computed for multiple time scales. To make use of both univariate and multivariate SDI allows, on one hand, to detect the effects of the deficit of water in more than one element of the hydrological system simultaneously and, on the other hand, to describe in detail the propagation of the deficit sign in along the hydrological cycle.

SDI are estimated as:

$$
S D I=\phi^{-1}(p)
$$

where $\phi$ is the standard normal distribution function and $p$ denotes the empirical probability of the elements in the sample, derived using the empirical Gringorten plotting position (Gringorten, 1963):

$$
p=\frac{i_{k}-0.44}{n+0.12}
$$

where $n$ is the sample size, $i_{k}$ is the rank of non-zero values sorted ascendingly. In the case of the MSDI, $i_{k}$ represents the number of occurrences of the triple $(x, y, z)$ for $x_{i} \leq x_{k}$ and $y_{i} \leq y_{k}$ and $z_{i} \leq$ $z_{k}(1 \leq i \leq n)$.

Droughts have been characterized following the approach of statistical runs, originally proposed by (Yevjevich, 1967). This approach defines the drought features through an analysis of the time series of a variable of interest (e.g., precipitation, soil moisture, and runoff). It consists in selecting a reference value $x_{0}$ which cuts the series at many places $\left(S D I_{0}=0\right)$. The relationship of $x_{0}$ to all other values of $x$ is interpreted as the water deficit intensity and serves as the basis for objectively identify the onset and termination of a drought and quantify its duration (distance between successive downcross and upcross), and its magnitude (sum of negative deviations between the successive downcross and upcross). Figure 2 shows the graphic representation of these features.

The value of drought intensity reflects the dry conditions in a time step basis, whilst the drought magnitude gives insight on the persistence of the event, given that it accumulates all the SDI values during its duration. Notably, while drought intensity is widely used to drought monitoring, drought magnitude has not been reported to be applied, although the simplicity of its computation. In order to make it easier to interpret by nontechnical public, in this framework the concept of magnitude (unitless, 
using SDI) is divided by an intensity threshold of $S D I=-1.3$, and expressed as drought duration if each month of the drought has the intensity of that threshold.

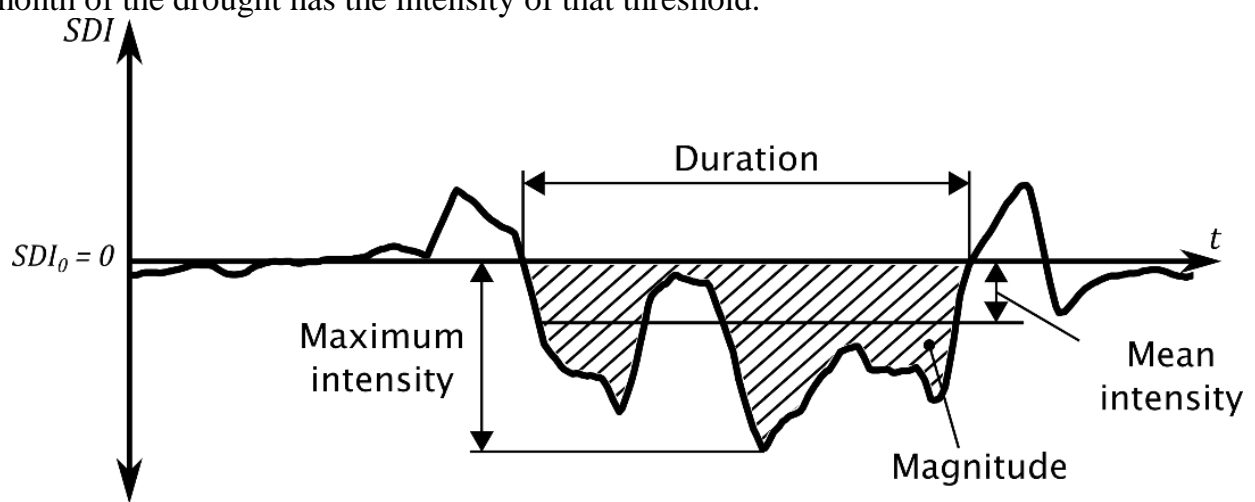

Figure 2. Drought features.

Drought intensity is classified using the SDI categories in Table 1, proposed by (Svoboda et al., 2002), and drought magnitude is classified through the proposed classification in Table 2.

Table 1. Categories of Drought intensity (SDI; (Svoboda et al., 2002)).

\begin{tabular}{|c|c|l|}
\hline$S D I$ value & Code & Drought category \\
\hline$S D I \leq-2.0$ & $\mathrm{D} 4$ & $\begin{array}{l}\text { Exceptional } \\
\text { drought }\end{array}$ \\
\hline$-2.0<S D I \leq-1.6$ & $\mathrm{D} 3$ & Extreme drought \\
\hline$-1.6<S D I \leq-1.3$ & $\mathrm{D} 2$ & Severe drought \\
\hline$-1.3<S D I \leq-0.8$ & $\mathrm{D} 1$ & Moderate drought \\
\hline$-0.8<S D I \leq-0.5$ & $\mathrm{D} 0$ & Abnormally dry \\
\hline$-0.5<S D I<0.5$ & & Normal \\
\hline $0.5 \leq S D I<0.8$ & $\mathrm{~W} 0$ & Abnormally wet \\
\hline $0.8 \leq S D I<1.3$ & $\mathrm{~W} 1$ & Moderately wet \\
\hline $1.3 \leq S D I<1.6$ & $\mathrm{~W} 2$ & Severely wet \\
\hline $1.6 \leq S D I<2.0$ & $\mathrm{~W} 2$ & Extremely wet \\
\hline$S D I>2.0$ & $\mathrm{~W} 3$ & Exceptionally wet \\
\hline
\end{tabular}

Table 2. Categories of drought magnitude (M).

\begin{tabular}{|c|c|}
\hline M value & $\begin{array}{l}\text { Magnitude } \\
\text { category }\end{array}$ \\
\hline $1 \leq M<3$ & M1 \\
\hline $3 \leq M<6$ & M2 \\
\hline $6 \leq M<9$ & M3 \\
\hline $9 \leq M<12$ & M4 \\
\hline$M \geq 12$ & M5 \\
\hline
\end{tabular}

\section{Case study}

The documented drought event during 2015-2017 in the state of Oaxaca, in the South of Mexico, is used here as the case study for evaluating the monitoring framework. Oaxaca is among the poorest regions of the country - in 2016, $70.4 \%$ of its population was in poverty conditions (CONEVAL, 2018) — The rainfed agriculture widely predominates in the state over irrigation, representing the 93 $\%$ of its agricultural land. These situations puts Oaxaca in a highly vulnerable condition to cope with droughts.

A review of impacts reported in newspapers allowed to reconstruct the chronology of the event. In August of 2015, the first effects of drought were represented by the loss of more than 43000 ha of crops of maize in the community of Asunción de Nochixtlán and 600 peasant families suffered the total loss of their production (Briseño, 2015). In September, the local delegate of the Ministry of Agriculture, 
Livestock, Rural Development, Fisheries and Food (SAGARPA) reported losses in 73000 ha of sorghum and maize crops (Notimex, 2015). In October of that year, in the localities of Puente Madera, Santa Rosa de Lima and Guichivere, Almost 300 floriculture producers observed partial losses of crops of cempasuchil and cresta de gallo (IstmoPress, 2015), widely traded during the All Saints holyday in the region, in November.

In the first trimester of 2016, farmers of Ciudad Ixtepec community reported the loss of the $90 \%$ of their harvest. The prolonged low precipitation conditions in the region provoked a fall in the storage level in the Benito Juárez dam, in Jalapa del Marqués. In March, the dam reported a $50 \%$ of its total capacity (El Universal, 2016). This year, as the precedent, losses in floriculture were reported in October. Only 70 of the 200 producers of cempasuchil and cresta de gallo were able to harvest their product (NSS Oaxaca, 2016).

In March of 2017, the Governor of Oaxaca requested to Federal authorities the declaration of emergency due to extreme drought in the south of the state, which would give access to financial aid from federation. The Benito Juárez dam storage dropped to $16 \%$ of its total capacity (López Morales, 2017). Estimations of livestock organizations report the loss of more than a thousand heads of cattle due to lack of food and water (Luciana, 2017). In April of that year, the National Water Commission started to support the region with the rehabilitation of 300 water wells for agricultural usage and authorized the drilling of 14 new water wells and the rehabilitation of 19 more for public urban usage, among other measures (Baptista, 2017). Figure 3 shows the location of the impacts reported during all the duration of the drought.

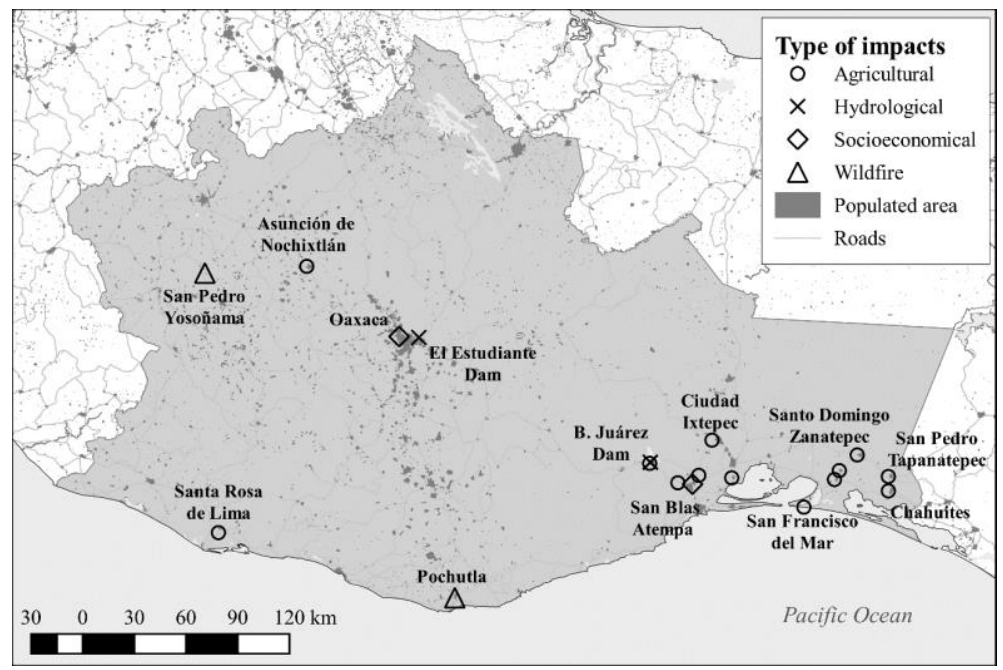

Figure 3. Impacts reported for the drought in Oaxaca during 2015-2017.

\section{Results}

The framework was applied to the case study of Oaxaca's drought of 2015-2017. The main products were the maps of intensity and magnitude, showed in Figure 4 and Figure 5. Results show the signature of a severe drought in most of the state with some parts exposed to extreme drought conditions. The variation of drought intensity and, overall, drought magnitude exhibits a good agreement with the impacts reported during the event. It worth to note that the request of declaration of emergency, in March of 2017, match with the period of higher magnitude of the event. 
The mapped results of the analysis were used to generate time series of the areal distribution of dray conditions. Figure 5 shows the time series of drought intensity and drought magnitude at the state level, where it becomes clear that the selected framework is able to follow-up the event from the beginning to the end.

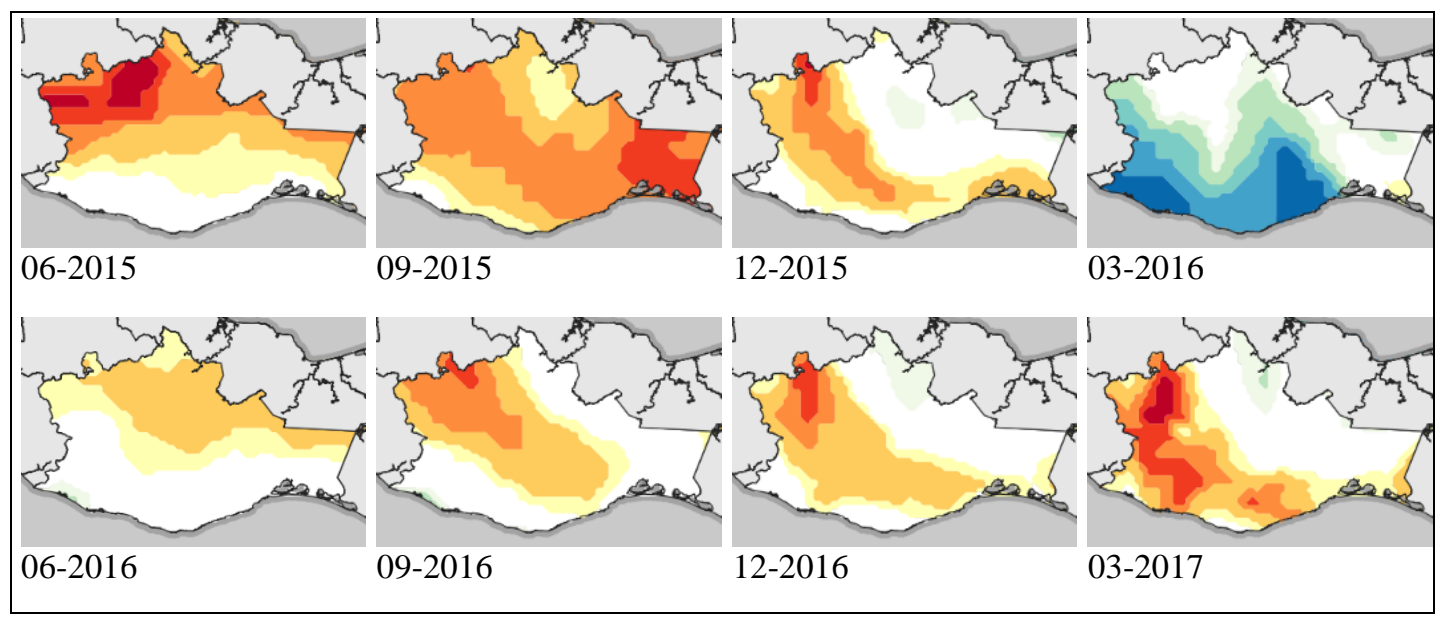

Figure 4. Evolution of drought intensity during the event of 2015-2017.

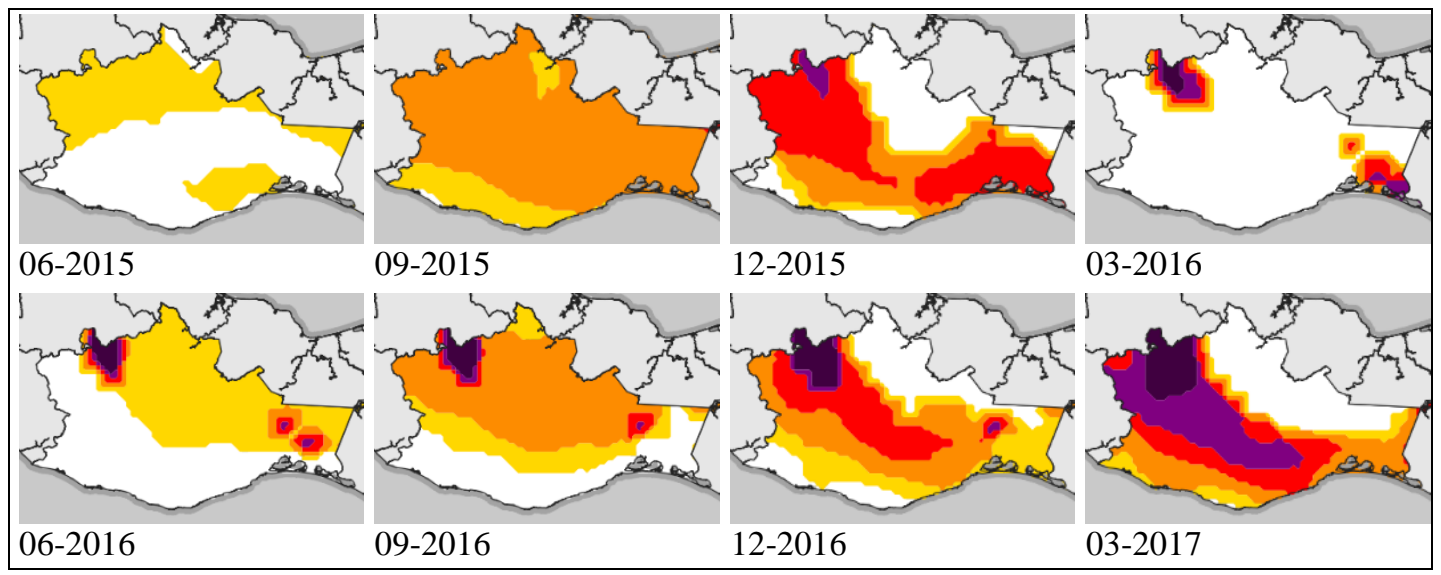

Figure 5. Evolution of drought magnitude during the event of 2015-2017.

\section{Conclusions}

The results of the framework have been compared with multiple drought events in Mexico, showing a good agreement with documented impacts.

Drought events examined so far, have shown a good agreement between results derived from the framework and documented impacts in all the studied regions. This has opened the door to the utilization of this framework in operational drought monitoring activities in Mexico, which are enabling a better decision-making related to these hydro-meteorological events and paves the road towards its use in other regions of the world, where data scarcity is an issue for drought monitoring activities. 


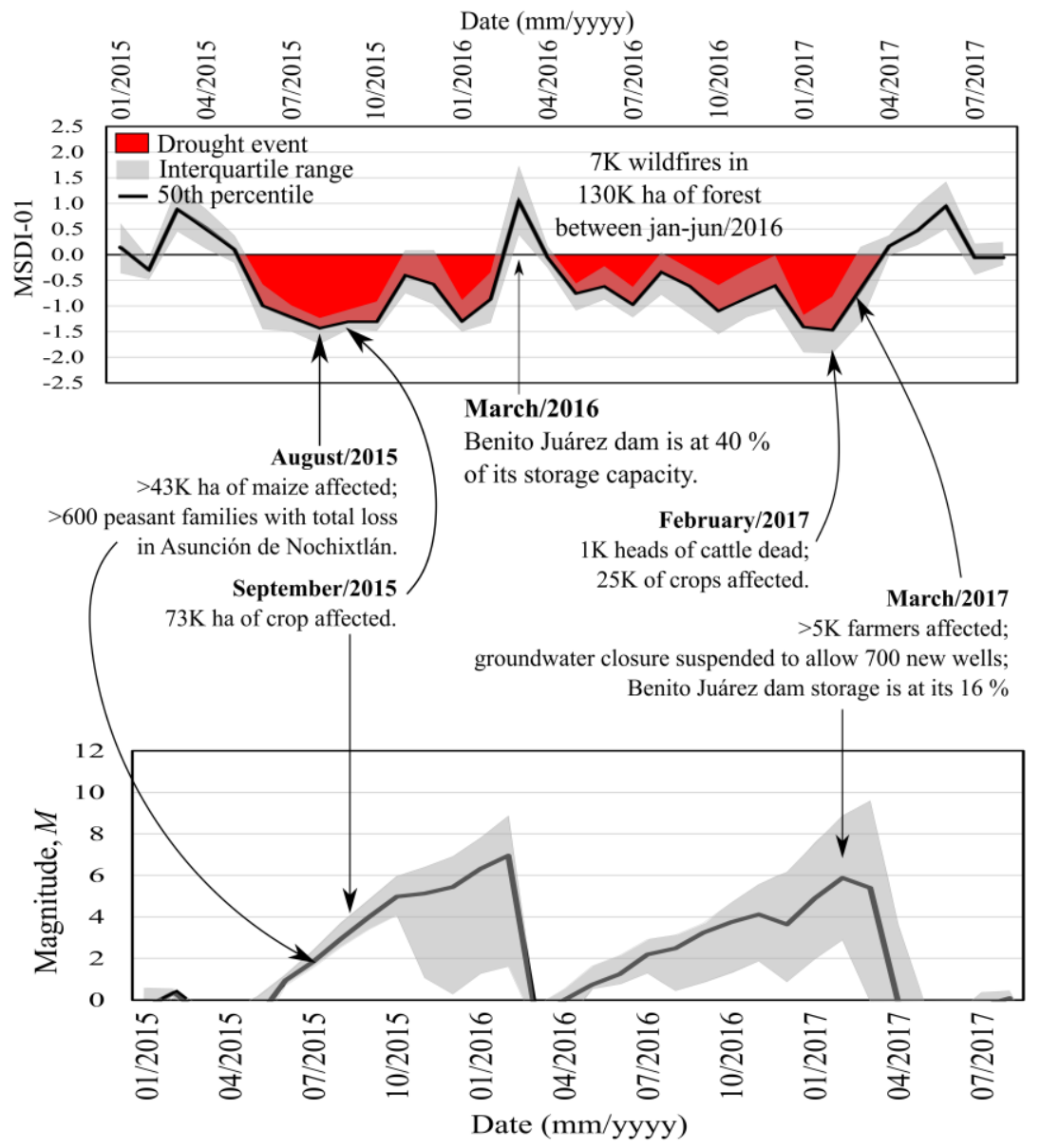

Figure 6. Time series of the Multivariate Standardized Drought Index for precipitation, soil moisture and total runoff and 1 month of time scale for Oaxaca.

\section{References}

Baptista, D. (2017, abril 6). Alertan por sequía en Oaxaca. Reforma. Recuperado a partir de http://diario.mx/Nacional/2017-04-06_d1ad89b0/alertan-por-sequia-en-oaxaca/

Briseño, P. (2015, agosto 31). Sequía pega a 100 municipios de Oaxaca; causa estragos en sembradíos. Excélsior. Recuperado a partir de http://www.excelsior.com.mx/nacional/2015/08/31/1043201

CONEVAL. (2018, febrero). Estadísticas de pobreza en Oaxaca. Recuperado a partir de www.coneval.org.mx

CRED. (2015). The human cost of weather related disasters: 1995-2015. The UN Office for Disaster Risk Reduction. https://doi.org/10.1007/s13398-014-0173-7.2

El Universal. (2016, marzo 9). Templo del siglo XVI emerge del agua en Oaxaca. El Universal. Recuperado a partir de http://www.eluniversal.com.mx/articulo/cultura/patrimonio/2016/03/9/templo-del-siglo-xviemerge-del-agua-en-oaxaca 
Farahmand, A., \& AghaKouchak, A. (2015). A generalized framework for deriving nonparametric standardized drought indicators. Advances in Water Resources, 76, 140-145. https://doi.org/10.1016/j.advwatres.2014.11.012

Gelaro, R., McCarty, W., Suárez, M. J., Todling, R., Molod, A., Takacs, L., ... Zhao, B. (2017). The Modern-Era Retrospective Analysis for Research and Applications, Version 2 (MERRA-2). Journal of Climate, 30(14), 5419-5454. https://doi.org/10.1175/JCLI-D-16-0758.1

Gringorten, I. I. (1963). A plotting rule for extreme probability paper. Journal of Geophysical Research, 68(3), 813-813. https://doi.org/10.1029/JZ068i003p00813

Hao, Z., \& AghaKouchak, A. (2013). Multivariate Standardized Drought Index: A parametric multiindex model. Advances in Water Resources, 57, 12-18. https://doi.org/10.1016/j.advwatres.2013.03.009

Hao, Z., \& AghaKouchak, A. (2014). A Nonparametric Multivariate Multi-Index Drought Monitoring Framework. Journal of Hydrometeorology, 15(1), 89-101. https://doi.org/10.1175/JHM-D12-0160.1

IstmoPress. (2015, octubre 26). El cempasúchil y la cresta de gallo, flores afectadas por la sequía en el Istmo de Tehuantepec. Noticias del Istmo, Oaxaca. Recuperado a partir de http://www.istmopress.com.mx/istmo/el-cempasuchil-y-la-cresta-de-gallo-flores-afectadaspor-la-sequia-en-el-istmo-de-tehuantepec/

López Morales, A. (2017, marzo 10). Oaxaca pide declarar emergencia por sequía. El Universal. Recuperado a partir de http://www.eluniversal.com.mx/articulo/estados/2017/03/10/oaxacapide-declarar-emergencia-por-sequia

Luciana, C. (2017, marzo 9). Oaxaca, el estado más golpeado por la sequía. NVI Noticias. Recuperado a partir de http://www.nvinoticias.com/nota/53466/oaxaca-el-estado-mas-golpeado-por-lasequia

McKee, T. B., Doesken, N. J., \& Kleist, J. (1993). The relationship of drought frequency and duration to time scales. En Eighth Conference on Applied Climatology (pp. 179-184). American Meteorological Society.

Notimex. (2015, junio 27). Sequía y lluvias afectan a estados de la República - 20minutos.com.mx. 20minutos.com.mx - Últimas Noticias. Recuperado a partir de https://www.20minutos.com.mx/noticia/b328525/sequia-y-lluvias-afectan-a-estados-de-larepublica/

NSS Oaxaca. (2016, octubre 27). Futuro incierto para productores de cempasúchil en Oaxaca. www.nssoaxaca.com. Recuperado a partir de https://www.nssoaxaca.com/2016/10/27/futuroincierto-para-productores-de-cempasuchil-en-oaxaca/

Shukla, S., \& Wood, A. W. (2008). Use of a Standardized Runoff Index for Characterizing Hydrologic Drought. Geophysical Research Letters, 35(2), 1-7. https://doi.org/10.1029/2007GL032487

Svoboda, M. D., LeComte, D., Hayes, M. J., Heim Jr., R. R., Gleason, K., Angel, J. R., ... Stephens, S. (2002). Drought Monitor. Bulletin of the American Meteorological Society, (April), 11811190. https://doi.org/10.1175/1520-0477(2002)083<1181:TDM>2.3.CO;2

UNISDR, \& WMO. (2012, mayo). UN System Task Team on the Post-2015 UN Development Agenda. Disaster risk and resilience: Thematic Think Piece. Recuperado a partir de http://www.unisdr.org/files/27462_20120607unttpostmdgthinkpieceondrra.pdf

Wall, N., \& Hayes, M. J. (2016). Drought and Health in the Context of Public Engagement. En S. L. Steinberg \& W. A. Sprigg (Eds.), Extreme weather, health, and communities: Extreme weather and society (pp. 219-244). Springer International Publishing Switzerland. https://doi.org/10.1007/978-3-319-30626-1_10

Yevjevich, V. (1967). An objective approach to definitions and investigations of continental hydrologic droughts. Hydrology Papers 23, (23), 25-25. https://doi.org/10.1016/0022-1694(69)90110-3 